\title{
Correlation of Fluorescent Appearance in Papilla with Unsuccessful Penetration Attempts in Susceptible Barley Inoculated with Erysiphe graminis f. sp. hordei
}

\author{
Nobuhiro KITA*, Hideyoshi TOYODA*, Tetsuo YANo** \\ and Jiko ShISHIYAMA* \\ 北 宜裕*・豊田秀吉*・矢野哲男**・獅山慈孝*：感受性オオムギ葉における

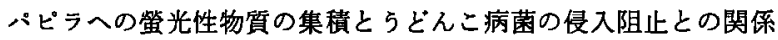

\begin{abstract}
In susceptible barley to Erysiphe graminis f. sp. hordei race I, the relation between fluorescent appearance in papilla and fungal penetration attempts was examined using light and fluorescent microscope. In the primary penetration course, fluorescent appearance was detected in all papillae where inoculated conidia ceased the penetration into host epidermal cells, whereas the papillae which permitted the successful penetration attempts did not show any fluorescent appearance. In halo, the same fluorescent appearance was observed regardless of success or failure of fungal penetration. These cytological responses were also observed in the secondary or tertiary penetration sites $72 \mathrm{hr}$ after inoculation. These results suggested that accumulation of fluorescent compound in papilla was essential for the prevention of fungal penetration in powdery mildew of barley.
\end{abstract}

(Received June 30, 1980)

\section{Introduction}

In resistant barley to Erysiphe graminis f. sp. hordei, race I, fluorescent appearance was detected in papilla, epidermal and mesophyll cells affected by fungal infection ${ }^{5,6,7)}$. In these fluorescent sites, no appreciable development of fungi was observed. In susceptible barley. most of inoculated conidia successfully penetrated into host epidermal cells and established their infections without any fluorescing at papilla. Other conidia, however, failed to penetrate into host cells by papillar formation ${ }^{2,3}$. In these papillae, some compounds such as fluorescent compound ${ }^{6)}$ or basic staining material ${ }^{1)}$ were accumulated. Therefore, these chemical depositions in papilla are considered to be responsible for decreasing the successful penetration of $E$. graminis $\mathrm{f}$. sp. hordei in both susceptible and resistant barley.

The present study was carried out to clarify the relation between fluorescent appearance in papilla and success or failure of fungal penetration attempts in susceptible barley inoculated with E. graminis f. sp. hordei.

* Faculty of Agriculture, Kyoto University, Kyoto 606, Japan 京都大学農学部

** Hokkaido Development Bureau, Obihiro Branch, Obihiro 080, Japan 北海道開発局帯広開発建設部 


\section{Materials and Methods}

A susceptible barley (Hordeum vulgare L.), Kobinkatagi, was grown in vermiculite at $20 \pm 1 \mathrm{C}$ in a growth chamber with photoperiod of $12 \mathrm{hr}$. Inoculation to the primary leaves was carried out 7 days after sowing by dusting conidia of Erysiphe graminis f. sp. hordei, race I. Inoculated plants were incubated at $20 \pm 1 \mathrm{C}$ in a moistened chamber with $100 \%$ r. h. for $3 \mathrm{hr}$ and replaced to the ordinary conditioned chamber mentioned above. The inoculated leaves were taken randomly at various periods after inoculation and decolored by boiling alcoholic lactophenol solution for 2-3 min. For microscopic observations, the top 1-4 cm portions of decolored leaves were dipped in lactophenol-aniline-blue solution for 2-3 sec to stain the inoculated fungi and rinsed with water for several times. The staining with aniline blue did not disturb the fluorescence in leaves. Light and fluorescent microscopic observations were carried out using a light and dark field of Nikon fluorescent microscope with blue excitation (excitation filter IF410-485, and absorption filter 515W). Only a germling that attacked a single host cell was counted.

\section{Results and Discussion}

Fluorescent appearance was detected in all papillae where inoculated conidia failed to penetrate into host epidermal cells (Table 1). On the contrary, papillae which permitted successful penetration did not show any noticeable fluorescence 18, 24 and $48 \mathrm{hr}$ after inoculation. Fluorescence in halo was observed at all infection sites regardless of success or failure of fungal penetration attempts.

Until $72 \mathrm{hr}$ after inoculation, inoculated conidia which succeeded the primary penetration and haustorial formation tried their secondary or tertiary penetration attempts (Table 2). In papillae which prevented the secondary or tertiary penetrations, fluorescent appearance was also observed (Fig. 1. see arrow 1). When successful penetration was accomplished, any fluorescent appearance was not observed in the penetrated papilla (Fig. 1. see arrow 2). Halo was also observed regardless of success or failure of fungal penetration attempts as observed in the primary penetration (Fig. 1-B).

Table 1. Relation between penetration attempts and fluorescent appearance in papilla in susceptible barley infected with $E$. graminis f. sp. hordei, race I

\begin{tabular}{|c|c|c|c|c|}
\hline \multirow{3}{*}{$\begin{array}{c}\text { Time after } \\
\text { inoculation } \\
\text { (hr) }\end{array}$} & \multicolumn{4}{|c|}{ Number of conidia } \\
\hline & \multicolumn{2}{|c|}{ unsuccessful penetration at } & \multicolumn{2}{|c|}{ successful penetration at } \\
\hline & f-papa) & non-f-pap ${ }^{b}$ & f-pap & non-f-pap \\
\hline 18 & 331 & 0 & 0 & $857\left(7^{c}\right)$ \\
\hline 24 & 200 & 0 & 0 & $779(28)$ \\
\hline 48 & 171 & 0 & 0 & $774(32)$ \\
\hline
\end{tabular}

\footnotetext{
a) fluorescent papilla

b) non-fluorescent papilla

c) partialy or slightly fluorescent papilla
} 
Table 2. Relation between secondary or tertiary penetration attempts and fluorescent appearance in papilla in susceptible barley infected with $E$. graminis f. sp. hordei, race I

\begin{tabular}{|c|c|c|c|}
\hline \multicolumn{4}{|c|}{ Averaged number of penetration sites per pustule } \\
\hline \multicolumn{2}{|c|}{ unsuccessful penetration at } & \multicolumn{2}{|c|}{ successful penetration at } \\
\hline f-papa) & non-f-pap ${ }^{\text {b) }}$ & f-pap & non-f-pap \\
\hline 1.8 & 0 & 0 & $8.2\left(0.2^{c}\right)$ \\
\hline
\end{tabular}

a), b) and c) Refer to Table 1

Penetration sites were observed $72 \mathrm{hr}$ after inoculation
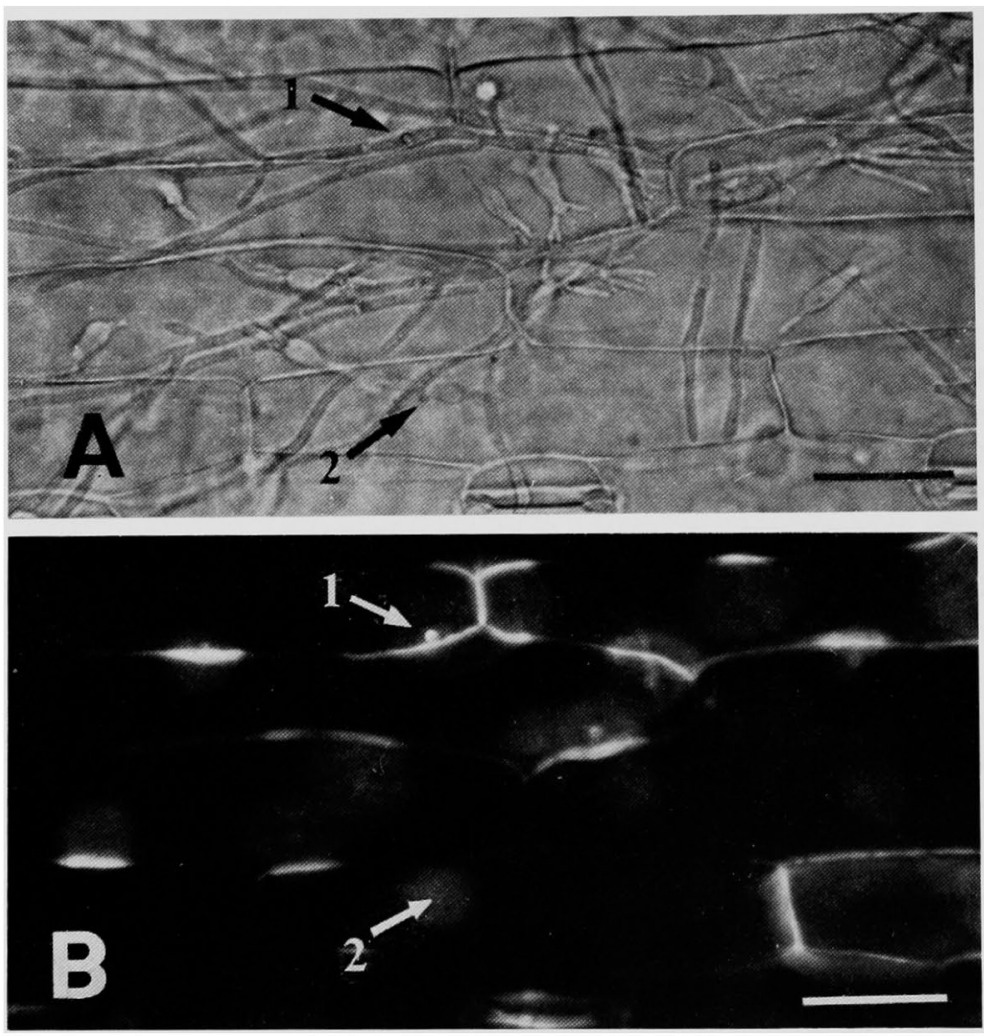

Fig. 1. Correlation of fluorescent appearance in papillae with unsuccessful or successful penetartion attempts at various infection sites of $E$. graminis f. sp. hordei, race $I$, on susceptible cultivar of barley $72 \mathrm{hr}$ after inoculation

A : Papillar and haustorial formation at various infection sites of a pustule under light microscope.

B : Fluorescent micrograph of A. Fluorescent appearance was observed in papilla (arrow 1) where fungal penetration was prevented. No fluorescence, however, was observed at papilla (arrow 2) where fungal penetration and haustorial formation were observed.

Scales in the micrographs represent $100 \mu \mathrm{m}$. 
In powdery-mildewed barley leaves, it has been postulated that papillar resistance to fungal penetration was attributed either to the accumulation of antifungal compounds in papilla or to the mechanical function of papilla ${ }^{1,4,8}$. The present study indicated that the accumulation of fluorescent compound in papilla was highly correlated with unsuccessful penetration attempts of pathogen even in susceptible leaves. These results suggested that the production or accumulation of fluorescent compound in papilla was essential for prevention of fungal penetration rather than mechanical function of papilla.

\title{
Literature cited
}

1. Edwards, H. H. (1970). New Phytol. 69: 299-301.

2. Johnson, L. E. B., Bushnell, W. R. and Zeyen, R. J. (1979). Can. J. Bot. 57 : 497-511.

3. Koga, H., Mayama, S. and Shishiyama, J. (1980). Ibid. 58 : 536-541.

4. Lin, M.R. and Edwards, H. H. (1974). New Phytol. 73: 131-137.

5. Mayama, S. and Shishiyama, J. (1976). Ann. Phytopathol. Soc. Japan 42: 591-596.

6. Mayama, S. and Shishiyama, J. (1978). Physiol. Plant Pathol. 13: 347-354.

7. Toyoda, H., Mayama, S. and Shishiyama, J. (1978). Phytopathol. Z., 92: 125-131.

8. Zeyen, R. J. and Bushnell, W. R. (1979). Can. J. Bot. 57: 898-913.

\section{和 文 摘 要}

\author{
感受性オオムギ葉に括けるパピラへの螢光性物質の集積と \\ らどんこ病菌の侵入阻止との関係 \\ 北 宜裕・豊田秀吉・矢野哲男・獅山慈孝
}

5 どんこ病菌, Erysiphe graminis f. sp. hordei, レースIを接種した感受性オオムギ品種コビンカタギ を用いて，パピラにおける螢光化とらどんこ病菌侵入の成否との関係を，接種18，24，48および72時間後に 調べた。第一次侵入部のパピラに蛨光化が認められた場合には，菌の侵入は抑えられたが，菌がハピラを貫 通し吸器を形成した場合には，そのパピラに䖝光化は起こらなかった。接種72時間後の第二次以後の侵入部 に拈いても同様ことが観察された。一方，侵入部周辺のハローには，貣穿の成否にかかわらず，螢光化が認 められた。以上のことから，オオムギらどんこ病菌の侵入阻止には，パピラへの䖝光性物質の集積が重要な 役割を果していると推論した。 